\title{
Differentiation strategies in coffee global value chains through reference to territorial origin in Latin American countries
}

\author{
Andrea Marescotti ${ }^{1}$ and Giovanni Belletti ${ }^{2}$ \\ ${ }^{1}$ Dipartimento di Scienze per 1'Economia e l'Impresa, Università di Firenze (I), Via delle Pandette, 9 - 50127, Italy \\ e-mail: andrea.marescotti@unifi.it (corresponding author) \\ ${ }^{2}$ Dipartimento di Scienze per l'Economia e l'Impresa, Università di Firenze (I), Via delle Pandette, 9 - 50127, Italy \\ e-mail: giovanni.belletti@unifi.it
}

Submitted: 08 July 2015. Accepted: 29 December 2015

\begin{abstract}
For many years coffee has been regarded as a commodity. Recently, new trends both at consumption and production level created new opportunities for de-commodifying the coffee market, by a differentiation based on social, environmental and territorial resources, and consequently for strengthening local agro-food systems and improving the position of farmers in the value chain. In this perspective, territorial origin is one promising lever of differentiation, and there is a growing number of initiatives trying to develop protected Geographical Indications in coffee value chains. This work aims at identifying the different logics surrounding the construction of protected Geographical Indications (GIs) in the coffee industry in Latin America, and to discuss the role of history and tradition in relation to the link to specific local resources. Our analysis highlights a variety of typologies of GI initiatives, which follow different logics and strategies, and interpret the concept of "origin" in different ways, especially when compared to the European Union one. However the role that history and traditions play in American coffee GIs is not yet relevant.
\end{abstract}

KEYWORDS: geographical indications; origin products; history; tradition; identity.

Citation / Cómo citar este artículo: Marescotti, Andrea and Belletti, Giovanni (2016) "Differentiation strategies in coffee global value chains through reference to territorial origin in Latin American countries". Culture \& History Digital Journal, 5 (1): doi: http://dx.doi.org/10.3989/chdj.2016.007.

RESUMEN: Estrategias de diferenciación de las cadenas globales del café en América Latina mediante la referencia al origen territorial.- Durante mucho tiempo, el café ha sido considerado como un producto commodity, de carácter indiferenciado. Recientemente, nuevas tendencias en la producción y el consumo de café han creado nuevas oportunidades para emprender estrategias de diferenciación (de-commodify) en el mercado del café, basadas en los recursos locales de carácter social, medioambiental y territorial y, consecuentemente, con una finalidad de impulsar los sistemas agroalimentarios locales y de mejorar la situación de los agricultores en la cadena de valor. Desde esta perspectiva, el origen territorial se convierte en una herramienta prometedora de diferenciación del producto. Existe un número creciente de iniciativas cuyo propósito es desarrollar Indicaciones Geográficas (IGs) en el ámbito de las cadenas de valor del café. Este trabajo tiene como objetivo identificar las diferentes lógicas de funcionamiento que tienen lugar en el ámbito de la construcción de IGs en el sector del café en América Latina, así como discutir el papel de la historia y la tradición como recursos locales específicos que vinculan el producto al territorio. Nuestro análisis pone de relieve una variedad de tipologías de iniciativas de IGs, que siguen diferentes lógicas y estrategias. El trabajo interpreta el concepto de "origen" de distintas maneras, particularmente en comparación con la normativa de la Unión Europea. No obstante, el rol de la historia y de la tradición no es aún especialmente relevante en el caso de las IGs americanas de café.

PALABRAS CLAVE: indicaciones geográficas; productos típicos; historia; tradición; identidad.

Copyright: ( 2016 CSIC. This is an open-access article distributed under the terms of the Creative Commons Attribution License (CC BY) Spain 3.0. 


\section{INTRODUCTION, APPROACH AND AIMS}

"Origin Products" (OPs) are products from a delimited geographical place where a noted quality, reputation or other characteristic of the good is essentially attributable to human and/or natural local specific resources used. Indeed, an increasing number of enterprises at different levels of the value chains refer to territorial origin - by means of Geographical Indications (GIs), where the geographical name of the production place identifies the OP on the market - as one of the key elements for implementing product differentiation strategies. But, even not considering the unfair and mystifying uses of GIs, the meaning attached to "origin" in the definition of food quality and identity is highly variable and contested, and this can negatively affect its effectiveness in signaling specific quality characteristics on the market.

In the Mediterranean countries of the European Union (EU), where the concept of GI was first defined and implemented, the reference to history and tradition is one of the pillars of the link of the OP to the territory, together with the use of local specific resources in the production process. In this context the OP, as "territorial identity-based" food, is often the expression of Local agro-food systems (LAFs), being explicitly grounded into specific territorial dynamics of agriculture, food, and consumption networks (Sanz Cañada and Macías Vázquez, 2005; Muchnik, 2010; Sanz Cañada, 2016). A slightly different approach is followed in many other countries, were both historical depth and the link of the product to production and consumption local traditions are not perceived as relevant in the definition of OPs identity.

The diverse cultural approaches to OPs affect the way GIs are protected by the Law across countries (ThévenodMottet and Marie-Vivien, 2011). In the EU and in a number of other countries in the world, the special nature of OPs prompted to create a specific legal frameworks dedicated exclusively to protect their names (sui generis systems), where producers are asked to provide scientific evidence of this link. However, even in the EU legislation a reference to history and to local traditions is not explicitly mentioned in Regulation 2081/1992 (that first introduced a normative framework for protecting GIs) and following amendments and regulations. In other countries the approach to GIs protection is deeply different, following the more liberal logic of collective trademark, and no particular evidence on the link between OP and its territory is asked.

In this paper, we analyze how the identity of the GI product is built and communicated by actors in the value chain, and what concepts and values are mobilized to build an origin-based identity to the product. We will specifically focus on protected GIs, which normally ask for a shared agreement among local enterprises on the specific quality characteristics of the product, its production rules, and the geographical boundaries where the production can take place. Indeed, it is along this process that one can understand how local actors shape the OP identity and which is the meaning of "origin" that they attach to the product. Therefore, considering that in the majority of protected GIs around the world the identity of the product is collectively defined by enterprises, the content of the Product specification (PS) ${ }^{1}$ and its agreement/writing process are at the core of the identity of the product.

The paper will focus on the coffee industry, where the issue of territorial quality has become highly relevant in recent years, and it can be considered as one of the key factors on which decommodification strategies can be built upon (Galtier et al., 2013). De-commodifying a market means to differentiate the product in order to reduce the substitutability between the suppliers, and consequently capture a higher share of the total added value (Galtier et al., 2008).

The paper aims at identifying the different logics surrounding the construction of protected GI identities in the coffee industry and the role of history and tradition, and exploring to what extent these logics offer opportunities in terms of decommodification potential. Coffee is a relatively "young" product in many important production areas, and the legal frameworks for GI protection relatively recent, too, as a result of the obligations from the TRIPS agreement that, since 1994, obliges all member countries to provide with some form of protection to GIs.

The paper is structured as follows. Section 2 presents a discussion about the role history and tradition play in shaping the identity of food products, with a special focus on the concept used in the EU. The specificities of coffee chains, the economic constraints in the coffee production and marketing for enhancing a process of de-commodification, and the role protected GIs are expected to play are analyzed in Section 3. Section 4 presents empirical findings about a number of case studies, and Section 5 develops a discussion on different meanings of origin in coffee protected GIs. General conclusions are proposed in Section 6.

\section{HISTORY, TRADITION AND IDENTITY OF ORIGIN-BASED PRODUCTS}

All the definitions of OPs are built around the idea that there must be a strong link between product quality and its territory ${ }^{2}$. OP quality attributes are directly linked to the specificity of a territorial context and cannot be reproduced in other places, i.e., outside that particular local economic, environmental, social and cultural context (Vandecandelaere et al., 2009).

According to the Mediterranean vision, mainly spread in Italy, France, Spain and Greece where this concept was first developed and framed, there are three interrelated dimensions that should characterize OPs: the specificity of local resources used in the production process; the history of the product (production and consumption traditions); and the collective dimension (Barjolle et al., 1998; Bérard and Marchenay, 2004 and 2006; Casabianca et al., 2011; Bowen and Mutersbaugh, 2014). 
The specificity of local resources determines the peculiarities of product quality attributes, stemming from the "physical" environment where the product is produced, and particularly the pedoclimatic, environmental and genetic resources (Belletti et al., 2012). Nevertheless, natural resources express their potential through growing, breeding, handling and processing practices, which are managed by local people with their skills and know-how, locally reproduced, adapted, and transmitted in time from one generation to the other. Moreover, there is a tradition of consumption specific to the place of origin, too: how and when to eat the product, how to prepare, cook and serve it, and how to assess its quality. This bundle of natural and anthropic specific local resources offers the opportunity to differentiate the OP on the market and to internalize values connected to the place, by this way allowing for enhancement, remuneration, reproduction and renewal of the local specific resources used for producing the OP. In this way, a "virtuous" circle is activated; the process is able to close and effectively achieve the reproduction and renewal of the resources used in a "complete" production process (Belletti and Marescotti, 2011).

The OP is considered as a social construct with historical roots, too. On the basis of a set of local resources, a group of individual actors (enterprises and users/consumers) and collective actors (producers' associations, interprofessional bodies, local administrations) build the OP identity over the course of time. Therefore, the ability to create value from an OP via the market mechanism, and the allocation of this value between different firms participating in the value chain, have not only a territorial but also a collective basis.

The link to the territory where the product come from, which is often indicated on the label by the name of the territory itself (the geographical indication), is of growing importance for both producers and consumers. For the consumer, the territorial origin becomes an indicator of the whole quality of the agri-food product.

At the same time the geographical indication associated to the OP becomes an important immaterial resource that producers can use in marketing their products. As we have seen, in many legal systems, GIs are acknowledged and protected against misuse and fraud by means of legal instruments and in some cases by special protection schemes (sui generis systems). The concept of GI is defined in the TRIPS Agreement (Art. 22.1) as follows:

Geographical indications are, for the purposes of this Agreement, indications which identify a good as originating in the territory of a Member, or a region or locality in that territory, where a given quality, reputation or other characteristic of the good is essentially attributable to its geographical origin.

The main question here is about the role of local resources and of history and tradition in defining the identity of GIs as quoted in TRIPS Agreement. EU Regulation 1151/2012 (that follows EU regulations 2081/1992 and
$510 / 2006)$ provides for a sui generis system of legal protection of GIs from imitations and abuses on the market. According to EU Regulation 1151/2012 (Art. 5):

For the purpose of this Regulation, "designation of origin' is a name which identifies a product: (a) originating in a specific place, region or, in exceptional cases, a country; (b) whose quality or characteristics are essentially or exclusively due to a particular geographical environment with its inherent natural and human factors; and (c) the production steps of which all take place in the defined geographical area.

For the purpose of this Regulation, 'geographical indication' is a name which identifies a product: (a) originating in a specific place, region or country; (b) whose given quality, reputation or other characteristic is essentially attributable to its geographical origin; and (c) at least one of the production steps of which take place in the defined geographical area.

The EU system makes a distinction between Protected Designation of Origin (PDO) and Protected Geographical Indication (PGI). For a PDO there must be an objective and exclusive link between product quality and its geographical origin. For a PGI product the link with the geographical area does not need to be "essential or exclusive" but has to be causal. In this sense, it is sufficient that the features or the reputation of the product are 'attributable' to the geographic origin.

When applying for a PDO or a PGI, producers have to demonstrate the intensity of the link between product quality and its place of origin. Indeed, although the regulation seems to be quite demanding as regards the demonstration of the link to origin, nothing is said about the nature of the resources to be mobilized to obtain the protection. In the case of PGI, producers have only to demonstrate the existence of a certain reputation. In the case of the PDO, where the strength of the link should be much higher, it is left to producers to decide which human or natural resource affect product quality. Even more important, although it is in the course of time that producers shape the identity of the product and consumers become aware of it, history is simply not there. As noticed by Bérard and Marchenay (1995), the EU Regulation on PDO and PGI does not ask producers to demonstrate that the GI product has a history and a tradition, but just that the (or a) quality attributes of the OP is directly related to the specificity of the place of production.

If all this refer to the general EU rules about PDO and PGI, what does change is the implementation made at single Member State level across the EU. Each Member State established its own procedures and rules to apply for a PDO or PGI (Sylvander, 2004). As a consequence, the demonstration of the link and the need to bring evidence of the historical character of the product differ a lot across countries, giving way to different "levels of historicalness and typicity" among registered PDO and PGI in EU.

These differences are even more evident if we consider the whole world. The concept of "geographical ori- 
gin" varies according to national cultures, as well as to different conceptions of "food quality." In countries that follow the "trademark approach" to GIs, the justification of the link between the OP and the territory can even be omitted as what is relevant is the will of the applicants, while the State is normally not directly involved in controlling the content of the PS. This attitude is mainly due to the dominant culture in these countries, where food is often perceived as weakly linked to history and traditions.

In both sui generis and trademark approaches, the link between product quality and local resources has to be defined by local actors themselves in the PS. On the basis of local production traditions and knowledge, local actors have to set out the geographical boundaries of the production system, the key points of the production process and the link to local specific resources. This is a very delicate and complicate issue, as stakeholders participating in the building up of the PS may display diversified if not conflicting interests about how to shape the rules. Depending on the way these different interests are mediated in the PS, the link between the product and local resources, and the link with the history and tradition of the production system, are strengthened or weakened.

How the concept of geographical origin, and geographical indication, is shaped greatly varies according to the type of product (e.g., processed or not processed product) and the characteristics of its local production system and supply chain. The analysis therefore needs to be contextualized in order to escape from generality.

\section{COFFEE CHAINS AND GEOGRAPHICAL INDICATIONS}

\section{The coffee world value-chain}

Coffee is the second most important commodity in world trade after oil, and a source of income for many people in rural areas of developing countries (Gerz and Avelino, 2006)

In order to understand the role protected GIs can play in adding value to coffee in relation to different interpretations States and producers give them, it is important to shortly recall the situation in the world coffee value chain.

World coffee production has always been characterised by high instability, with a large crop in one year frequently followed by a smaller crop in the next. This trend affects prices levels, which are subject to considerable instability, too.

In the last fifty years, with the exception of Africa, all coffee-growing regions evidence a steady growth in their production, as well as exported quantities, with the exception of some period of market crisis (ICO, 2014). Brazil is the world leader producing and exporting country, together with Vietnam, Colombia, and Indonesia (table 1).

The coffee value chain is highly complex, due to its length in terms of production steps (many actors intervene along the production process from farmers to final consumers) and to the geographical distance between the upstream (production of green coffee) and downstream phases of the production process.

TABLE 1 . Total coffee production by all exporting countries (In thousand $60 \mathrm{~kg}$ bags).

\begin{tabular}{|l|c|r|r|r|r|r|}
\cline { 3 - 7 } \multicolumn{2}{l|}{} & $\mathbf{2 0 1 1 / 1 2}$ & $\mathbf{2 0 1 2 / 1 3}$ & $\mathbf{2 0 1 3 / 1 4}$ & $\mathbf{2 0 1 4 / 1 5}$ & $\begin{array}{c}\mathbf{2 0 1 3 / 1 4} \text { and } \\
\mathbf{2 0 1 4 / 1 5} \text { in \% }\end{array}$ \\
\hline Brazil & (A/R) & 43.484 & 50.826 & 49.152 & 45.342 & $32,7 \%$ \\
\hline Vietnam & (R/A) & 26.500 & 25.000 & 27.500 & 27.500 & $19,1 \%$ \\
\hline Colombia & (A) & 7.652 & 9.927 & 12.124 & 12.500 & $8,5 \%$ \\
\hline Indonesia & (R/A) & 7.288 & 13.048 & 11.667 & 9.350 & $7,3 \%$ \\
\hline Ethiopia & (A) & 6.798 & 6.233 & 6.527 & 6.625 & $4,6 \%$ \\
\hline India & (R/A) & 4.921 & 4.977 & 5.075 & 5.517 & $3,7 \%$ \\
\hline Honduras & (A) & 5.903 & 4.537 & 4.568 & 5.400 & $3,5 \%$ \\
\hline Mexico & (A) & 4.563 & 4.327 & 3.916 & 3.900 & $2,7 \%$ \\
\hline Uganda & (R/A) & 3.075 & 3.878 & 3.602 & 3.800 & $2,6 \%$ \\
\hline Guatemala & (A/R) & 3.840 & 3.743 & 3.159 & 3.500 & $2,3 \%$ \\
\hline Peru & (A) & 5.373 & 4.453 & 4.338 & 2.883 & $2,5 \%$ \\
\hline Others & & 17.174 & 16.644 & 15.173 & 15.416 & $10,6 \%$ \\
$-\begin{array}{l}\text { Dominican Republic } \\
- \text { Jamaica }\end{array}$ & (A) & 491 & 488 & 425 & 400 & $0,3 \%$ \\
\hline Total & (A) & 24 & 24 & 20 & 20 & $0,0 \%$ \\
\hline
\end{tabular}

A = Arabica; $\mathrm{R}=$ Robusta.

Source: International Coffee Organization. 
Today the key role in the global coffee value chain is played by actors located in developed countries, especially large green coffee traders and multinational firms operating in the roasting and final distribution phases. Coffee exchanges in international market are highly concentrated in the hands of a few international trading companies. Concentration rate is increasing in the roasting phase, too. Changes in roasting technologies and organization are reported as being factors affecting the dynamics of the supply-chain and the demand. Concentration in the roasting phase is mainly due to oversupply, increased flexibility in blending and the implementation of "supplier-managed inventory" (Ponte, 2002).

World coffee consumption increased at an average annual growth rate of $1.9 \%$ over the last 50 years (ICO, 2014). Japan, the EU and the USA have traditionally accounted for the majority of global coffee demand and consumption. However, in recent years, while consumption in non-producing countries is only slowly growing, demand in coffee-producing countries and emerging markets have expanded significantly. Indeed, consumption in producers' countries has been estimated being over 30\% of the total supply and it is still growing, together with consumption in emerging markets (ICO, 2014).

Most coffee is exported as "green", while roasting and grounding phases - the more adding-value phases - are normally developed in consuming countries. Roasters use to make blends of coffees from different qualities, geographical origins and varieties (Robusta and Arabica) to homogenize product characteristics on the market. The import market is dominated by the EU and the USA, followed by Japan.

\section{Opportunities and limits for decommodifying the coffee market}

Coffee is gradually losing its commodity nature, as a number of differentiation criteria have been emerging on the market, based on social and environmental sustainability, coffee quality characteristics, place of production.

Since the 1930s', green coffee has been a commodity classified according to few internationally agreed criteria, and in particular the variety (Arabica or Robusta), the type of post-harvest process (washed or unwashed), and the grade (bean size and number of defects). The commodification of the coffee market allows roasters to easily switch between coffees from different geographical origins by substitution of different varieties, process and grades (Daviron, 2006), thus reducing their costs without compromising the stability of the taste of their final product (the grounded coffee). But it is mainly after the abandonment of the International Coffee Agreement in 1989 that this process of coffee commodification has been described as a problem for exporting countries and for producers (Galtier et al., 2013). As pointed out by Daviron and Ponte (2005) a "coffee paradox" emerges, characterized by decreasing and unstable prices to farmers on the one side and increasing consumer prices on the other side: the value of coffee on the final market today is not so much linked to the raw material (green coffee). Rather, it is connected to the ways of combining different coffees in blends, roasting and marketing (symbolic attributes), and by services provided in bars and coffee shops (Muradian and Pelupessy, 2005). As a consequence, firms operating downstream in the supply chain (mainly located in consumer countries) are able to satisfy changing consumer's needs and add value to the product without involving upstream firms. The coffee market has consequently turned from a producer-driven market to a buyer-driven commodity supply chain (Gereffi et al., 2005; Ponte, 2002; Rueda and Lambin, 2013).

Nowadays the growth of interest in "specialty coffees" is one of the most important trends in international coffee market and in consuming countries, and it is expected to offer a way to escape the commodification of the value chain. As a matter of fact, prices for specialty and high-quality coffees resisted the price crisis better than standard and low-quality coffees, and paved the way for a new form of competition on the market based on "global niches" and on a set of quality attributes of the product and the production process.

Although specialty coffees are not precisely defined, they cover a wide range of differentiation aspects that make them differing from traditional industrial blends: shadegrown coffees ${ }^{3}$, altitude ${ }^{4}$, Arabica vs. Robusta ${ }^{5}$, environmental care, social equity and fair distribution of final price, and so on (Ponte, 2002; Lewin et al., 2004). Quality schemes based on the guarantee of such attributes are spreading all over the producing countries: organic, GLOBAL-GAP standard, fair-trade, Rainforest Alliance, Bird Friendly, Common Code for the Coffee Community (4C), Utz Kapeh are the most common (Raynolds et al., 2007).

However, according to some scholars (Daviron and Ponte, 2005), the benefits from these differentiation tools are not equally shared along the supply chain. In particular, the real benefits for smallholders are often very low, with the partial exception of Fair trade schemes, which aim at guaranteeing a fixed return to smallholders and other social benefits.

What is disputed is that these standards are designed in the downstream part of the coffee chain, either by buyers or other organizations (public institutions, NGOs, etc.) not directly involved in trade, and that they have the same content all over the world, with only minor adaptations to local specificities (Galtier et al., 2013). For that reason these quality labels have been interpreted as an extension of the standardization process to new social and/or environmental attributes. Therefore, their contribution to the "decommodification" of the market is questionable due to the growing interest of coffee growers in these new market macro-segments and to the consequent internal competition that reduces economic returns for coffee farmers, who at the same time had to face increased production costs in order to comply with standards and to certify their production process (Daviron and Vagneron, 2011; Kaplinsky and Fitter, 2004; Bacon, 2005; Neilson and Pritchard, 2007; Raynolds et al., 2007; Neilson, 2008; Raynolds, 2009; Galtier and Diaz Pedregal, 2010). 


\section{Mobilizing territorial origin: the role of Geographical Indications}

Territorial origin is another, and potentially alternative, way of differentiating coffee on international markets (Galland et al., 2006). The claim of geographical origin is not new for coffee marketing, but up to recent times it mainly affected the intermediate market of green coffees.

Indeed, at the beginning of the history of coffee $\left(18^{\text {th }}\right.$ and $19^{\text {th }}$ centuries), origin essentially meant the estate where coffee had been produced, coupled with the name of the departure port where the green coffees were shipped (Mochas, Bourbon, Javas) or sometimes the country. Therefore, we can state that initially the international market for green coffee was highly decommodified.

Although this "old" system has not completely disappeared (there is a small niche market for "estate coffees"), with the development of future markets and the emergence of family farms producing coffee before the World War II, the organization of the market completely changed (Daviron, 2002). Smallholder coffee productions entered on the market, together with the development of traders instead of simply commissioners. Big producing and exporting countries then created their own national standards, often supported by a strong presence of the State in regulating exportations (up to give a monopoly on export to State Agencies or Marketing boards). Geographical origin of coffee turned then to essentially mean country of provenience (Daviron, 2006). The use of the name of the country on the coffee bags was often regulated by Coffee State Agencies and authorized only for the higher quality grades. Only in a few special cases the names of the most reputed and/or famous production territories were used to signal top quality grades, sometimes even though the top quality coffee was not produced in that particular region. As a result, territorial origin (national or local) became but one of the many differentiation tools in the hands of production countries to signal specific qualities mainly linked to grades to big traders and roasters. This was the situation prevailing after World War II, although with some deviations.

Later on, following the liberalization wave of the 80's in twentieth century, national standards have been losing their significance in favour of global and /or corporate quality standards. On the consumer market the indication of the country was, and still is, perceived as a very general quality cue, linked to an "halo country of origin" (for example, Brazil and Dominican Republic are perceived by Italian consumers as "good" coffee producers, with a long tradition; and this depends also on the fact that some Italian traders were based from ancient times in these countries). Origin (national or local) became but one of the many differentiation tools in the hands of production countries to signal specific qualities mainly linked to grades to big traders and roasters.

Only recently the indication of geographical origin (or provenance) reached the final consumer too, creating a real market for single-source origin. In the coffee value chain a flourishing number of initiatives linked to the use of geographical names (country of origin, specific areas, fancy names like mountains or other renamed places ...) can be observed.

Also in coffee producing countries the debate on the use of geographical names is rapidly rising (Teuber, $2010 \mathrm{~b}$ ), as well as controversies and conflicts on the legitimate use of them. ${ }^{6}$ The situation at international level is complex due to both differences in legal GIs frameworks and the incompleteness of many of them.

In coffee producing countries we observe different "philosophical" orientations and interpretations of origin. As discussed in previous sections, this implies different "visions" of GIs and different roles of the State in their support and legal protection, which in a number of coffee producer Countries is still incomplete. This incompleteness of normative frameworks on GIs derives from the fact that many of them are very recent in times (Barjolle et al., 2013). In fact the growth of origin coffee has been prompted by the decisions taken within the TRIPS agreement, which oblige WTO member States to enforce legal protection of Geographical Indications (as defined by art.22 of TRIPS Agreement). For this reason many coffee producing countries have built GI normative frameworks only recently; but very often these young GI normative frameworks are not yet well implemented and consolidated, especially in the GI post-registration phases: control systems and enforcement apparatus are often lacking, making ineffective the GI legal registration.

What is at stake here is the potential of GI protection to act as de-commodifier of the coffee market, thus allowing producers to directly manage and benefit from this differentiation tool. The peculiarity of the GIs lays on the fact that, opposite to what happens for other differentiation tools, the rules are set by producers themselves, taking into account both the specificity of the product and its local production system, and the need to market the product. The rules contained in the PS can therefore be considered as a flexible tool-box in the hands of producers to build appropriate GIs to attain strategic objectives on the market. As a consequence, the way local producers build the PS, and also communicate the link of the product to the territory to both intermediate and final consumers, is the result of both the specificity of the product and the strategic orientation towards the market.

Giving the peculiarities of the coffee market and the structure of the global value-chain, producers who want to use the GI protection tool have to face additional difficulties.

Probably the most important weakness of GIs in the coffee world stems from the length and complexity of the value chain, whose head is located in consumption countries. For that reason it is difficult to preserve the identity of the coffee beans coming from a single territorial origin up to the coffee cup. Indeed, as above mentioned, roasters use blends of coffees from different territorial origins and quality characteristics to make a product with stable characteristics and firm's specific features, and they sometimes perceive communicating GIs to final consumers as 
a threat for their business, when GIs force roasters to use that particular product.

At the same time the legal protection granted to a GI in the production country is often not valid in the consumption ones; the extension of the protection (and of the enforcement), due to the incompleteness of TRIPS agreements on GIs for products other than wines, need for specific bilateral agreements between States, or special applications to the European Union that recognizes third countries GIs following a specific procedure (up to now only Café de Colombia GI was recognized as PGI in the $\mathrm{EU})$, or again a registration of the GI as a trademark in the consuming country, that is very expensive and doesn't give a high level of protection.

\section{ANALYZING COFFEE GIS}

\section{Framing coffee GIs typology and methodology}

In this paragraph some GIs in the coffee market are presented in order to show the diversity of the ways local producers strategically conceive the protection of the GIs, negotiate the rules in the PS, and communicate to customers and final consumers. The aim is to identify what are the logics driving the choices by actors involved in the supply chain and what place specific resources, history and tradition have in shaping the identity of these GI coffees.

A number of GIs coffees were identified to cover different situations on the basis of available information. These GIs have been analyzed by means of two main sets of information: the main characteristics of the PS, and the way these products are communicated to buyers by means of "official" tools (like the Internet, or other public-domain sources). In the cases of Pico Duarte (Dominican Republic) and Blue Mountain (Jamaica) coffees, authors' direct knowledge (based on interviews to local institutions, coffee farmers and other supply chain actors and some focus groups) integrated these first two sources (see Belletti and Marescotti, 2013; Galtier et al., 2013 for more details).

Selected cases will help to illustrate the diversity of meaning attached to GIs for coffee, depending on actors' strategy and coffee specificities. As pointed out, PSs are at the crossroad of different actors categories, each of them bringing specific vision of the product and its qualities linked to their respective interests. PSs should first of all define the name to be protected, which is the "geographical indication": this is a relevant issue, as different names have different values, reputations, and evocative power towards consumers. Besides, the PS delimits the production area: in the case of coffee it is not relevant only "horizontal" geographical boundaries but also the altitude (being the quality of coffee beans linked to altitude, a number of PS normally exclude lower areas inside a given territory). Again, the PS defines the key characteristics of the production process at different stages of the supply chain (farming, first processing, and so on), including the link to specific resources as specific coffee varieties, farming practices linked to specific soil conditions, local know-how, and so on. Finally, the PS provides the key characteristics of the final product, that is the cured coffee bean (green coffee) and, in some cases, the roasted coffee too. Internal grading grids are often provided by the PS, in order to identify different qualities inside the same GI.

The most evident feature of the protected coffee GIs is the extension of the geographical area included in the GI. Two different typologies emerge. The first refers to country GIs, where the geographical names and territorial coverage encompasses the whole national production. We selected Colombia, that accounts for $8,5 \%$ of world green coffee production in the last two years (table 1), and more than half million coffee farmers, and Guatemala, 2,3\% of world green coffee production with 90000 coffee farmers. The second typology is related to GIs referring to small territories and quantities. Blue Mountain Coffee from Jamaica ( $0.02 \%$ of world green coffee production, 8000 farmers), Pico Duarte Coffee from Dominican Republic (30000 bags, $0.0002 \%, 600$ farmers), and Marcala Coffee from Honduras (1500 farmers) will provide examples of this typology.

\section{Country GIs}

The selected examples of "country-GIs" refer to Colombia and Guatemala: these GIs encompass an entire country, or at least all coffee regions inside the country, but their characteristics are different. This approach is in line with the past situation of the international coffee market, when the reference to the country of the coffee beans was a basic quality grading tool, mainly signaling to intermediary purchasers an average consuetudinary way of producing, processing and grading coffee beans (Belletti et al., 2015). Qualifying coffee by means of country of provenance was reinforced by the big role some States have played in regulating international exchanges, by means of public control of export qualities and public mandatory marketing boards (Daviron and Ponte, 2005). In this way some countries acquired a good reputation on international market, which is now incorporated into these national GIs.

\section{Colombia coffee}

Colombia is perhaps the most known coffee GI in the world. This is due to some specific conditions. The Colombian coffee GI was born as an extension of a collective trademark owned by the Colombian coffee growers' federation (Federación Nacional de Cafeteros - FNC) and enjoying a good reputation on international markets. The main aim of the GI protection was obtaining the sui generis protection granted by the EU GI protection system; the PGI Colombia was registered by the EU in 2007. Following the same logic of the national trademark, the strategic aim of the GI protection was to qualify the whole national production and increase the recognizability of the name both by final consumers and downstream actors in the chain (roasters in consumer countries) (Schüßler, 2009; Quiñones-Ruiz et al., 2015).

For that reason the PS is quite basic and generic, in order to let the protected GI accessible to most of national coffee production and producers. In the application filed to 
EU for the PGI registration, the link between coffee quality and territory is mostly based on climatic conditions, on soil characteristics in which the crop is grown, and on the coffee-producing culture of the country. All these features, as the document presented to the EU for the registration states, "may be applicable to a number of other coffee producing countries or regions of the world", but "the existence at the same time of the natural, human and traditional factors and reputation mentioned, as well as of the inspection arrangements and processes discussed in the subsequent chapters, cannot be replicated in any coffee-growing area or region other than the Colombian Coffee-Growing Area." Tradition and history are mobilized not as much to set rules in the PS, rather to build a narrative to consumers and to support the demonstration of the acquired reputation of Colombia coffee on the market.

The main target firms of Café de Colombia GI are international coffee traders and roasters, and only indirectly final consumers. Having a big production under the same "umbrella", customers can find inside the same GI different coffee qualities and grades, thus allowing them to make their own blends even from only one origin.

Recently the FNC registered other more specific GIs: Café de Nariño and Café de Cauca, registered as Denomination of Origin. Even these two coffees are described on the basis of their quality characteristics, and "justified" on the basis of more specific climatic and soil conditions of the two production areas (sunlight hours per year, rainfall per year, rainfall patterns, organic material in the soils, altitudes), but no specific mention is made about other kind of local resources - as the human ones, like cultural tradition and local know-how. This is part of a wider branding strategy that should allow Colombian producers to satisfy the growing demand of single-origin coffees by final consumers, especially on US market and by large coffee retailers and bar-shops.

\section{Guatemala coffee}

Guatemalan coffee GI is a hybrid situation, a bit far from the extreme of pure country-GI. In this case the national-wide GI is conceived as a sort of umbrella mark covering different regional coffees.

The Guatemala government together with the Guatemalan National Coffee Association (ANACAFE) made a pioneering effort to define on scientific basis the country's coffee-producing regions. Eight regions were identified and delimitated, characterized in terms of both quality of coffee and territorial identity. These regions present specific characteristics in terms of climatic and pedological conditions for coffee production that reflect in the quality profile of coffee. At the same time these regions enjoy different reputations, too, also thanks to naturalistic or historical reasons not strictly linked to coffee production. Some of these regions already enjoyed a protected geographical indication, like Antigua and Acatenango, while others are still not well known and reputed.

These regional GIs, thanks to communication campaigns, are collectively valorized and promoted thanks to the national "Guatemalan coffees" trademark. The aim of this initiative is to develop a worldwide market (by means of a single brand) but trying to preserve specific identities of different coffee-producing territories. Roasters are the main target, but some specific marketing initiatives are also addressed directly to final consumers. The two logics of quality standard and of local identity are in this way both preserved.

\section{Small GIs}

The three selected examples of "small GIs" come from Dominican Republic, Jamaica and Honduras. Designing a GI on a smaller area offers the opportunity to activate bottom-up processes for the definition of rules and to adapt these rules to specificities of Local agro-food systems and of the local environment. As we see, these opportunities are not even exploited by local actors.

\section{Pico Duarte coffee (Dominican Republic)}

A first interesting case refers to the Pico Duarte coffee GI in Dominican Republic (Galtier et al., 2013). The process for the GI registration was activated by a scientific study funded by French international cooperation that set out the quality characteristics of coffee in the different production areas of Dominican Republic (Galtier et al., 2007; Escarramán et al., 2007). Specifically, in the inner part of the island, a number of potential GIs were identified. In the area of Jarabacoa, the process that led local producers to apply for the protection of the GI was meant mainly to achieve homogeneity in coffee quality, prompted by both local and external buyers' need to count on stable quality characteristics of green coffee supplies. Given this framework, it is evident that the application for the GI was not intended to protect an acquired reputation. Rather, it aimed at achieving a higher reputation thanks to both the settingup of a control and traceability system, and higher and standardized minimum quality level.

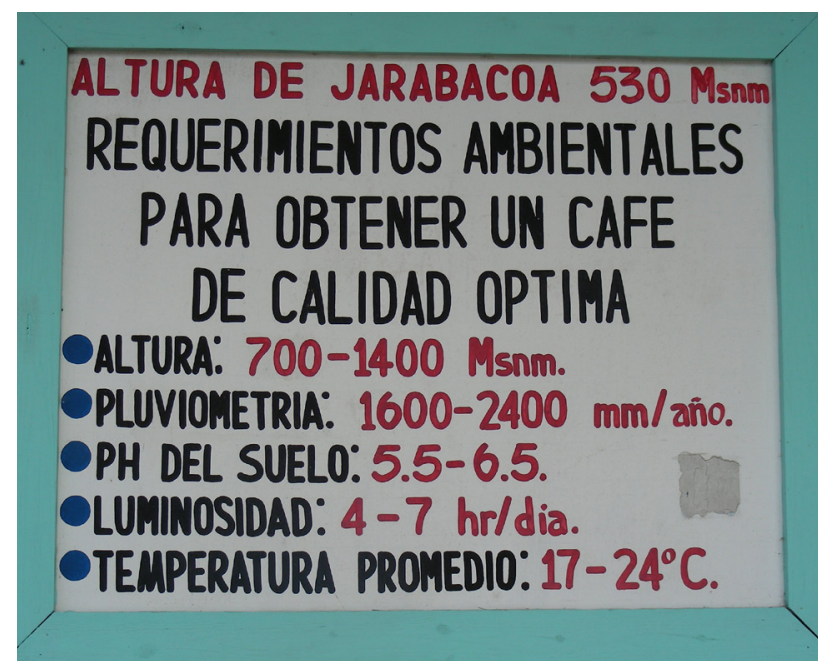

Рното 1. Environmental requirements for quality coffee production in Jarabacoa region (Dominican Republic). 


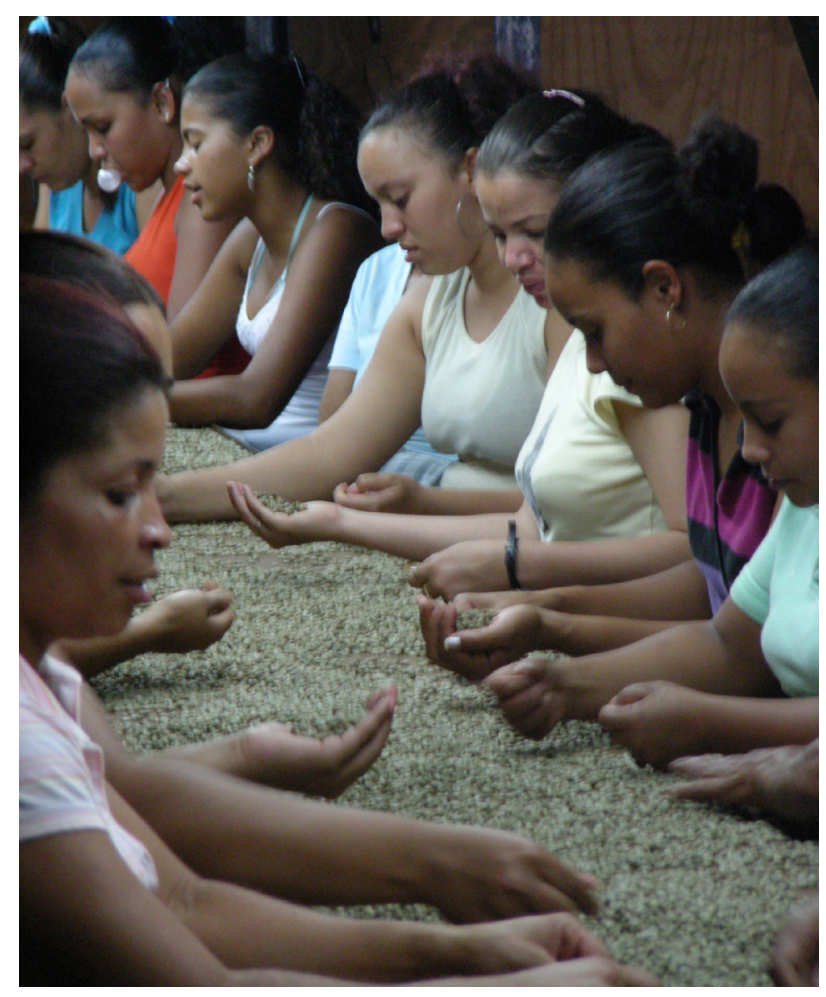

Рното 2. Coffee selection in Jarabacoa region (Dominican Republic).

As a consequence, the debate among local actors focused on technological aspects of the coffee production process and green coffee quality rather than on specific local territorial resources (although the area is characterized by high biodiversity and environmental richness), local production tradition, history, culture. That is why, rather than preserving traditional techniques and know-how, the rules have rather the aim of changing traditional production practices in order to improve coffee beans quality and meet commercial standards on intermediate markets.

As a result, although the process hasn't yet brought to formalize the application, the PS was conceived in a way as to select production areas inside the delimitated geographical boundaries (excluding lower areas, and other neighboring areas).

\section{Blue Mountain coffee (Jamaica)}

Another "small" coffee is the Jamaica Blue Mountain. Jamaica produces a very small part of the world total green coffee production, but the price of Blue Mountain coffee is by far the highest in the world. The Blue Mountain coffee supply chain is very original, compared with other coffee producer countries, where until recently green beans were sold as commodities. This coffee supply chain is well structured and strongly regulated by the Jamaican law, and managed by the Coffee Industry Board (CIB). More than 7000 farmers produce this world famous coffee across only about 5000 ha at between 600 and 1500 meters above sea level.

Blue Mountain area has the appropriate characteristics for the cultivation of high quality coffee: the climate (cool mountain temperatures with great variations, misty with high rainfall), shaded mountain slopes and lush vegetative cover which provide shade for the coffee plants, soil volcanic with a high drainage. For Blue Mountain (BM) coffee, typicality stems from a very specific ecosystem, which allows the variety Arabica Typica to develop special flavour and aroma. Hand harvesting, pulping and sun drying were identified as crucial steps that may improve or damage quality.

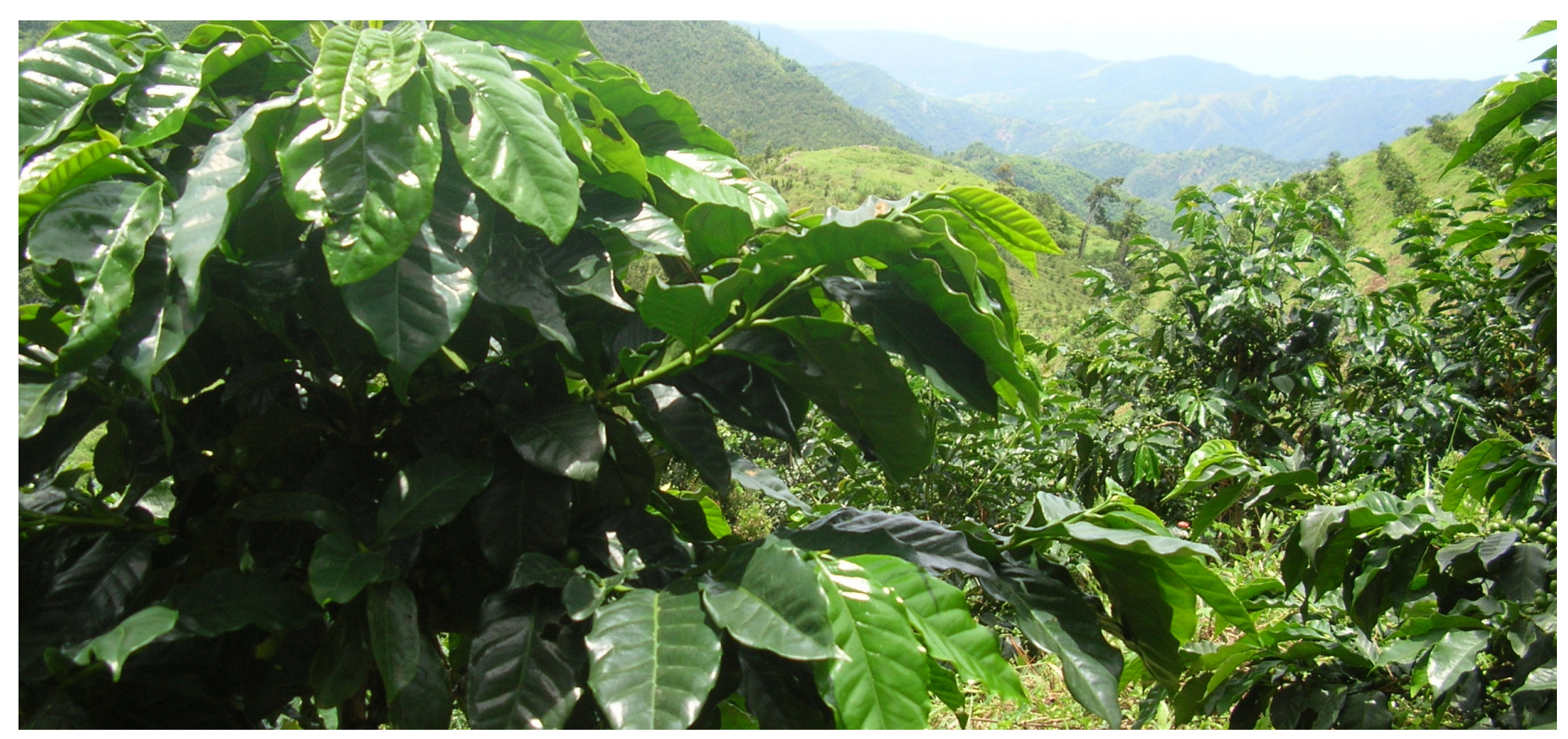

Рното 3. Coffee plantation in the Blue Mountains (Jamaica). 
On average $60-70 \%$ of the production is exported as green coffee (most to Japan, then the United States, Cana$\mathrm{da}$, and the UK), and $40-30 \%$ is roasted locally depending on the quality of the harvest year by year. About $60 \%$ of locally-roasted coffee is then exported or taken away by visitors (both for in place consumption and for taking coffee at home), while the other part is consumed locally.

Even though Jamaica Blue Mountain coffee exports are very dependent on the Japanese market, there appear to be other markets willing to recognize and pay for this particular origin. Although the overall crop is quite limited, also due to some difficulties on Japanese market, Jamaican producers are looking to develop new markets and the CIB has thus worked toward GI legal recognition and protection worldwide in producing nations as well as consuming nations (Schroeder, 2009), that had to be based on national general law on coffee production and quality grading, and the already registered trademark Jamaica Blue Mountain coffee. Therefore, writing the PS was quite a simple matter, thanks to previous rules established by Jamaican law with regard to the boundaries of the Blue Mountain production area, the production process, and green coffee quality characteristics.

The main aim of the registration of Blue Mountain coffee as a GI was to allow a better protection against imitations and abuses, also thanks to lower protection costs and better enforcement that could be obtained by registering the GI in other countries, and especially in the European Union (Belletti and Marescotti, 2013). This would allow to enter new markets and diversify market- ing channels, which is a part of a strategy Jamaica is pursuing, especially for European market where consumers are much more used and confident to GIs. Consequently, the PS retrieved some of the general norms about coffee production in Jamaica, without giving too many details on the production techniques (e.g. shade vs sun growing) and almost nothing on environmental aspects, nor on coffee-berries quality.

\section{Marcala coffee (Honduras)}

In the Marcala coffee case GI protection is used as a means to strengthen direct marketing channels to final consumers, counting on a strong territorial identity (Chaves, 2011). Marcala region enjoyed a certain reputation on the internal market, and its name was usurped by other coffees from Honduras (Osorto, 2007; Teuber, 2010a) engendering a loss of reputation and lower coffee prices paid for genuine Café de Marcala. This was the first motivation for starting the process for the GI registration, which was obtained in November 2005. Café de Marcala has been not only the first DO in Honduras but also the first in Central America.

In the Marcala GI pedological, climatic, and human factors are all relevant in the definition of coffee quality. In this small region (the delimited GI area covers 19 municipalities in three different Departments) the cultivation of coffee started in the Eighteen century and some specific techniques were developed. The PS is however focused on technical issues, as in the other big and small coffee

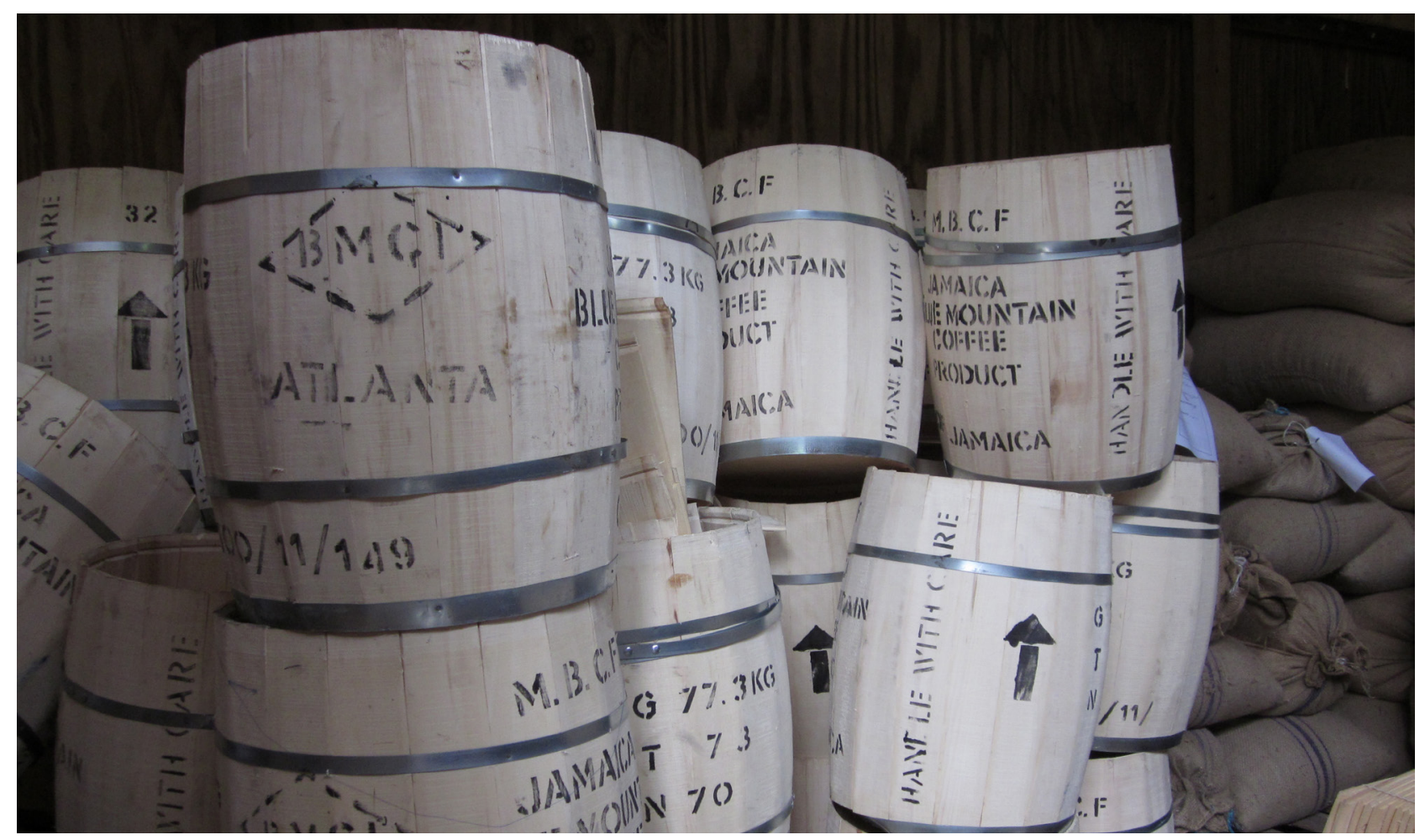

Рното 4. Blue Mountains Green Coffee barrels (Jamaica). 
GIs: the area was delimitated with reference to a deep study about agro-climatic conditions and related qualities of coffee (cup profiles). The process of registration was bottom-up, with a good involvement of local producers (Onori, 2013).

What characterize this GI initiative is its strong link with the local coffee production system and the territory that develops also in the management of the initiative. The consortium accounts for 2400 associates, not only coffee farmers (2300) but also intermediaries, exporters, brokers and roasters. The consortium develops collective actions focused on many issues: it supports the control of compliance with the PS, organizes collective promotion initiatives, and develops new niche marketing channels (coffee shops, alternative supply-chains, small roasting houses, etc.). It also supports producers' groups in accessing new markets, thanks to the collaboration with some Non-governmental organizations. Finally, the GI Marcala consortium supplies technical assistance to help famers to comply with traceability system and to meet quality standard as defined in the PS.

\section{DISCUSSION}

The cases presented in the previous Section show a diversity of situations as far as the rationale of GI coffee protection is concerned. This diversity goes beyond the divide between country GIs and local GIs and results from the role local resources have in shaping the identity of GI coffees and in supporting local agro-food system dynamics.

Country GIs encounter many difficulties in establishing a real link to local specific resources, know-how and practices. This is first of all due to the high variability of coffee production conditions and coffee production systems inside the same country, and at the same time to the need to cover with the GI a big part of the national coffee production in order to reduce exclusion effects from the use of the name of the country (Akaki, 2011).

In country GIs like Colombia the concept of origin is close to the concept of "provenance", even though reinforced by a set of quality rules (and grades of quality) that often come from the previous set of rules set up by State Agencies or Boards or by strong producers associations (as in the case of Colombia). The main aim in this cases is the search for an "halo country of origin" effect (Agrawal and Kamakura, 1999), built also thanks to narratives based on the general image of the country instead of on real links of the coffee production process to local specific resources. Guatemala coffee is a bit different case, because the national brand is built in order to increase the visibility of a number of regional GIs, some of them preexisting and already enjoying a protection. We could say that the national trademark acts to communicate the "provenance" of Guatemala GI coffees.

From a marketing point of view, country GIs have more potential to achieve, by means of differentiation strategies based on GI protection, final markets and consumers, having higher capacity to support marketing investment on brand reputation thanks to the big quantities they can cover and the notoriety the name of the country enjoy for its evocative power. Moreover, large coffee production and the diversity of territorial pedoclimatic conditions inside the delimitated area allow customers on intermediate markets (exporters, importers, roasters) to select needed supplies to create and stabilize their own blends. When clear and well-controlled PSs are in place, the GI protection helps buyers to carefully check green coffee quality characteristics and lots homogeneity. ${ }^{7}$ In other terms, for roasters it is the "recipe", rather that the territorial origin, that does matter (where recipe means the blend of different coffees and the roasting intensity). In these cases, communicating to consumers the territorial origin of the coffees used in the blend may even complicate life to roasters, who would have to change their blends to stabilize the final quality (Daviron, 2006). This may be especially the case of small but reputed GIs (i.e. Blue Mountain from Jamaica, Yirgacheffe from Ethiopia, Kona from Hawaii). That is why to date roasters (and supermarkets, too) prefer to use "large" GIs or even simple provenance from quite big producing countries (i.e. Colombia, Brazil, India, Kenya), thus preserving a great deal of freedom.

As a consequence, in the setting up of the PS, country GIs usually don't show much interest in inserting too specific production rules or environmental constraints, which eventually can be communicated through marketing activities "outside" the PS. In case, some more specific protected GIs can be created under the umbrella of the Country GI to satisfy certain needs by roasters.

At the same time, these country GIs strategies bear the risk of leveling prices of different territories with different qualities and production costs inside the same country, so losing specific territorial identities. Anyway, a process that is now ongoing is the search for an internal differentiation inside large country GIs. While nationwide GIs aim at protecting and exploiting the reputation of the name of the entire country, some regional GIs aimed at enhancing locally specific coffees have been developed.

Small GIs display a more differentiated and articulated situation. Generally speaking the small territorial area facilitates the participation of coffee growers in the process of defining the PS, thus giving the opportunity to design bottom-up GIs with more emphasis on the role of local identities and resources. In small GIs the actors of the local agro-food system are more conscious that GI protection can help to preserve the local resources on which the coffee system is based, thus contributing to its sustainability. However this rootedness in the territory is not even the final result, depending on a great variety of factors and local situations that affect the building process of the GI. Two main factors explaining small GIs features are the reputation the GI has acquired on the intermediate and final markets, and the target market producers want to address their strategy.

When coffee quality reputation is high (such as in Jamaica Blue Mountain Coffee), the GI protection is mainly meant to defend the reputation on the market. Therefore there is no need to "overcharge" the PS with too strict 
rules and to anchoring too much quality characteristics to specific local resources and production tradition, as these can be communicated within targeted marketing campaigns. Of course quality levels must be kept high, but not necessarily increased, as reputation has already been gained on the market and it is not so necessary to show to intermediate and final customers a strong effort for improving quality, but rather seriousness in quality controls.

When coffee quality and GI reputation is not yet high, the GI protection acts as a quality characteristics stabilizer on intermediate markets, while final consumers are simply not a stake. In these cases (as in Pico Duarte GI) the issue is rather to establish the minimum quality level admitted for using the protected GI.

Low quality level would lower production costs, and make the use of the protected GI more accessible; on the other side there would be the risk of weakening product identity with regard to competitors, with negative effects in the mid and long term. High minimum quality levels support the creation of a strong identity and differentiation, but in these cases production (and control) costs may heavily increase, and at the same time the number of producers using the GI (and quantity of GI-certified product) could be too small to be relevant on the market and benefit from scale economies in collective marketing activities. Only when local specific resources (plant-varieties, farming and processing techniques, history and culture, traditions and know-how) do count to determine green coffee quality, then they can be taken into account even in the PS. As underlined by Hughes (Hughes, 2009), legal protection of a local GI only helps preserve local traditions and resources if the product's unique qualities depend on these factors.

As far the target market is considered, some small GIs are targeted on intermediate markets (as Pico Duarte GI). For this reason they are conceived as technical standards, and pay little attention to local specific resources, history, and tradition. The aim of these GIs is qualifying the coffee with regard to some technical characteristics (defects and organoleptic profile) guaranteed by a certification system. No, or few, efforts are made for promoting the coffee on the final market. Other small GIs (like Jamaica Blue Mountain and Marcala coffees) are mainly targeted on final markets; the aim of the GI is to help the local production system to skip the intermediation of local and international traders and big roasters and to sell directly to small roasters in consuming areas (both in their country and abroad) interested in selling "unique" coffees to their customers. These GIs try to transfer to consumers the specific identity of the product and the reference to local specific features of production system and environment can be of great importance.

\section{CONCLUSIONS}

For a long time coffee has been regarded as a simple raw material, and this tendency increased with the increase of power of big trading and roasting multinational firms. In recent years new trends both at consumption and production level created new opportunities for a differentiation based on social, environmental and identity factors, and consequently for strengthening local agro-food systems and improving the position of farmers in the value chain.

In this perspective, geographical origin is one promising lever of differentiation, and there is a growing number of initiatives trying to develop protected GIs in coffee value chains. Our analysis highlights a variety of typologies of GI initiatives, which follow very different logics and strategies and interpret the concept of "origin" in different ways.

At one end of this continuum there are some big country-GIs, set up following top-down logics, with a low involvement of territories of production and with no or few links with local resources. On the opposite side of the continuum we found a few small GIs rooted in local agrofood systems, where local actors have built identity and reputation by strengthening the tie between coffee quality (in both its tangible and intangible aspects) to territorial specificities such as local culture and traditions, environmental characteristics, peculiar cultivation practices and know-hows.

However the role that history and tradition play in coffee GIs is not relevant in general terms, due to both the relatively recent introduction of coffee in many production areas, and to the fact that coffee is not perceived by producers as an identity product but mainly as a raw material sold to intermediaries and not linked to local consumption habits. In addition, the recent introduction of the concept of GI and of regulatory frameworks in many coffee production countries causes a limited culture and skills on the GI even by the side of institutions responsible for GIs. Many people do not even know the meaning of it, and maybe interpret it as a quality certification scheme as many others, without attaching special values deriving from "terroir" and "local agro-food system" logics.

Therefore the concept of GI in the coffee value chain is often quite different from the European (and in particular, Mediterranean) one, which puts much emphasis on the terroir effect as quality differentiation strategy. Conversely, even in small coffee GIs the logics are more inspired by a "standard quality" approach, where GI aims at reaching a homogeneous and high level of quality on the market but with less attention to the human, historical, and cultural specificities of coffee quality of the area.

Even when locally specific resources are mobilized to shape the identity of some small GIs, they are only rarely explicitly considered in the PS. However, the definition of more territorially rooted GIs requires multidisciplinary studies aimed at identifying the agro-ecological factors and cultivation practices that contribute to cup quality profiles and to the reputation of the product, and the contribution of coffee cultivation practices to the environment. A dialogue between supply chain actors is also needed in order to define locally shared and really enforceable rules. This is an approach more 
resource (and policy) demanding than country GIs in terms of research and technical assistance, and more expensive in terms of efforts per ton of coffee (Belletti et al., 2015).

In principle, country GIs can play relevant roles for supporting national coffee value chains although as sideeffect they can jeopardize local agrifood systems with specific characteristics and identities. Our analysis confirms that small dimension of the delimited territory is not per se a guarantee of the rootedness of the GI in the local agrifood system, as the main key features are rather both the internal actors' coordination and organization, and their capability to incorporate local resources into product identity (Torres Salcido and Muchnik, 2012; Giacomini and Mancini, 2015). Territory-rooted coffee GIs should be built thanks to bottom-up processes involving the actors of the local agro-food system, in order to be more able to generate long-lasting differentiation processes and to support local agro-food systems trajectories (Muchnik and Sautier, 1998). Normally, GIs cannot provide alone the solution for the coffee valorization, in particular when the problem to solve is not only the protection from unfair imitations. Territory-rooted GIs can be integrated in comprehensive territorial strategies elaborated by local actors in order to valorize the product and local resources involved in its production process. In this sense GI can play not only the role of a quality scheme, but it can become a governance tool for the whole localized agro-food production systems.

\section{NOTES}

1 The Product Specification is a document which contains the rules producers must comply with in order to use the GI, especially in relation to the description of the product and the method of obtaining it, and the definition of the geographical area where the process must take place.

2 Origin products are named differently in different countries and according to different cultural contexts. For example in Italy they are often named "typical products", in France "produits de terroir", in Spain "productos tipicos".

3 Shade-grown coffee is produced from coffee plants grown under a canopy of trees. Besides exerting positive effects on the environment and biodiversity preservation, shade-grown coffees are considered superior to that of full-sun coffee and less bitter. Shade allows coffee-cherries to mature more slowly and produce fewer cherries so that the flavor is more concentrated.

4 The altitude of the crop is the criteria of quality most recognized by coffee buyers, being directly correlated with the acidity of coffee, a required quality attribute for many consumers.

5 Arabica is considered the high quality coffee, richer in aroma and sweeter and softer taste and with higher acidity, while Robusta variety has a stronger and harsher taste, richer in caffeine and it is normally used for its body and structure.

6 See for example the debate over the registration in U.S. of some Ethiopian geographical names of coffees (Harrar, Sidamo and Yirgacheffe) as trademarks or certification marks (Teuber, 2010b), and the dispute between the Ethiopian Government and the US coffee retailer Starbucks, or the recent registration of Café de Colombia as PGI according to EU Regulation 510/2006.

7 As pointed out by Daviron, the problem for buyers can be summed up as " $a$ comparison-judgement between the cost of carrying out the checks needed to make sure a supply meets their expectations, and the extra cost involved in buying a designated product" (Daviron, 2006: 34).

\section{REFERENCES}

Agrawal, J. and Kamakura, W.A. (1999) "Country of origin: A competitive advantage?". International Journal of Research in Marketing, 16 (4): 255-267. doi: 10.1080/0965254X.2011.599497.

Akaki, P.P. (2011) "Denominaciones de origen (DO) y marcas colectivas (MC) en el café mexicano, ¿estrategia para el desarrollo regional?". Revista Geográfica de América Central, Numero Especial EGAL, 2 (47): 1-22.

Bacon, C. (2005) "Confronting the Coffee Crisis: Can Fair Trade, Organic, and Specialty Coffees Reduce Small-Scale Farmer Vulnerability in Northern Nicaragua?". World Development, 33 (3): 497-511. doi: 10.1016/j.worlddev.2004.10.002.

Barjolle, D.; Bernardoni, P. and Renard, O. (2013) Etude du potentiel de la commercialisation des produits agricoles des pays $A C P$ (Afrique, Caraïbes, Pacifique) utilisant les indications géographiques et les marques avec origine $(A C P-A G G I)$. Study by REDD SA Lausanne, financed by the European Commission (AGRI-2012-EVAL-05), Décembre. http://ec.europa.eu/agriculture/external-studies/2013/gis-acp-countries/fulltext_fr.pdf [accessed 5/February/2016].

Barjolle, D.; Boisseaux, S. and Dufour, M. (1998) Le lien au terroir. Bilan des travaux de recherche. ETH, Institut d'économie rurale, Lausanne.

Belletti, G.; Casabianca, F. and Marescotti, A. (2012) "Local food quality and local resources". In Local agri-food systems in a global world: Market, social and environmental challenges, edited by Arfini, F.; Mancini, Maria C. and Donati, M. Cambridge scholars publishing, Cambridge: 71-95.

Belletti, G. and Marescotti, A. (2011) "Origin products, GI special protection schemes and rural development". In Labels of Origin for Food. Local Development, Global Recognition, edited by Barham, E. and Sylvander, B. CABI International. Cambridge, USA: 75-91.

Belletti, G. and Marescotti, A. (2013) "Evaluating GI registration effects by means of participatory methods. First insights from a Jamaican case". Paper presented at XXV ESRS (European Society of Rural Sociology) Congress Rural resilience and vulnerability. The rural as locus of solidarity and conflicts in times of crisis, Florence, July-August.

Belletti, G.; Marescotti, A. and Touzard, J.M. (2015) "Geographical Indications, Public Goods and Sustainable Development: The roles of actors" strategies and public policies". World Development, in press. doi:10.1016/j.worlddev.2015.05.004.

Bérard, L. and Marchenay, P. (2004) Les produits de terroir. Entre cultures et règlements. CNRS editions, Paris.

Bérard, L. and Marchenay, P. (2006) "Local products and geographical indications: taking account of local knowledge and biodiversity". International Social Science Journal, 187: 109-116. doi: 10.1111/j.1468-2451.2006.00592.x.

Bérard, L. and Marchenay, P. (1995) "Lieux, temps et preuves: la construction sociale des produits de terroir". Terrain. Carnets du Patrimoine ethnologique, 24: 153-164.

Bowen, S. and Mutersbaugh, T. (2014) "Local or localized? Exploring the contributions of Franco-Mediterranean agrifood theory to alternative food research". Agriculture and human values, 31 (2): 201-213. doi: 10.1007/s10460-013-9461-7.

Casabianca, F.; Sylvander, B.; Noël, Y.; Beranger, C.; Coulon, J. B.; Roncin, F. and Giraud, G. (2011) "Terroir et typicité. Un enjeu de terminologie pour les Indications géographiques". In $L a$ mode du terroir et les produits alimentaires, edited by Delfosse, C. Les Indes Savantes, Paris: 101-117.

Chaves, A.R. (2011) "Denominaciones geográficas protegidas (DGP): oportunidad comercial para el patrimonio centroamericano". Revista Nacional de Administración, 2 (1): 91-110.

Daviron, B. (2002) "Small Farm Production and the Standardization of Tropical Products". Journal of Agrarian Change, 2 (2): $162-184$.

Daviron, B. (2006) "Coffee qualities and territories: an historical viewpoint". In Coffee: terroirs and qualities, edited by Montagnon, C. Editions Quae. Versailles: 21-36. 
Daviron, B. and Ponte, S. (2005) The coffee paradox. Global markets, commodity trade and the elusive promise of development. Zed Books, London.

Daviron, B. and Vagneron, I. (2011) "From commoditisation to decommoditisation... and back again. Discussing the role of sustainability standards for agricultural products". Development Policy Review, 29 (1): 91-113. doi: 10.1111/j.1467-7679.2011.00515.x.

Escarramán, A.; Romero, J.M.; Almonte, I.; Ribeyre, F.; Aguilar, P.; Jiménez, H.; Causse, A.; Olivares, F. and Batista, I. (2007) Determinacion de los atributos de calidad del café en zonas productoras de la Republica Dominicana. IDIAF-CODOCAFE: Santo Domingo.

Galland, J.C.; Avelino, J.; Larrain, A. and Montagnon, C. (2006) "Origin coffees: are Appellations of Origin on the horizon?". In Coffee: terroirs and qualities, edited by Montagnon, C. Editions Quae. Versailles: 49-68.

Galtier, F.; Belletti, G. and Marescotti, A. (2008) Are Geographical Indications a way to "decommodify" the coffee market? Paper presented at XII European Association of Agricultural Economists (EAAE) Congress, Ghent: 26-29 August. http://EconPapers.repec.org/RePEc:ags:eaae08:43834.

Galtier, F.; Belletti, G. and Marescotti, A. (2013) "Geographical Indications for coffee: can they decommodify the market and increase fairness?". Development policy review, 31 (5): 597-615. doi: $10.1111 /$ dpr. 12027

Galtier, F.; Del Rosario, P.; Camilo, J.; Santos, U.; Romero, J.; Jimenez, H.; Contreras, T. and Contreras, J. (2007) Caracterización Socioeconómica de las Empresas Cafetaleras en la República Dominicana. IDIAF; Santo Domingo.

Galtier, F. and Diaz Pedregal, V. (2010) "Le développement du commerce équitable peut-il conduire à une réduction des injustices? Une réflexion à partir du cas du café". Cahiers Agricultures, 19 (1): 50-57. doi: 10.1684/agr.2009.0369.

Gereffi. G.; Humphrey, J. and Sturgeon, T. (2005) "The governance of global value chains". Review of International Political Economy, 12 (1): 78-104. doi: 10.1080/09692290500049805.

Gerz, A. and Avelino, J. (2006) "Costa Rican Arabica Coffee: Legitimacy for specialty". In Origin-based Products. Lessons for pro-poor market development, edited by Van de Kop, P.; Sautier, D. and Gerz, A. Royal Tropical Institute and Cirad, Bulletin 372, Montpellier, France.

Giacomini, C. and Mancini, M. C. (2015) "Organisation as a key factor in Localised Agri-Food Systems (LAFS)". Bio-based and Applied Economics, 4 (1): 17-32. doi: 10.13128/BAE-15088.

Hughes, J. (2009) Coffee and chocolate - can we help developing country farmers through geographical indications? International Intellectual Property Institute, Washington D.C.

ICO (2014) World coffee trade (1963-2013): A review of the markets, challenges and opportunities facing the sector. International Coffee Council, 112th Session 3-7 March 2014, London, United Kingdom

Kaplinsky, R. and Fitter, R. (2004) "Technology and globalisation: who gains when commodities are de-commodified?". International Journal of Technology and Globalisation, 1 (1): 5-28. doi: 10.1504/IJTG.2004.004548.

Lewin, B.; Giovannucci, D. and Varangis, P. (2004) Coffee Markets: new paradigms in Global Supply and Demand. The World Bank, Agriculture and Rural Development Discussion Paper 3 , Washington D.C

Muchnik, J. (2010) "Localised agri-food systems: concept development and diversity of situations". Sviluppo Locale, 35: 3-20.

Muchnik, J. and Sautier, D. (1998) Systèmes agroalimentaires localisés et construction de territoires. ATP CIRAD, Montpellier, France.

Muradian, R. and Pelupessy, W. (2005) "Governing the coffee chain: the role of voluntary regulatory systems". World Development, 33 (12): 2029-2044. doi: 10.1016/j.worlddev.2005.06.007.

Neilson, J. (2008) "Global Private Regulation and Value-Chain Restructuring in Indonesian Smallholder Coffee Systems". World Development, 36 (9): 1607-1622. doi: 10.1016/j.worlddev.2007.09.005.

Neilson, J. and Pritchard, B. (2007) "Green Coffee? The Contradictions of Global Sustainability Initiatives from an Indian Per- spective". Development Policy Review 25 (3): 311-331. doi: 10.1111/j.1467-7679.2007.00372.x.

Onori, G. (2013) Prodotti agricoli commodity e strategie di branding. Opportunità delle Indicazioni Geografiche nella filiera del caffè. MSc Thesis, University of Firenze.

Osorto, Diana (2007) Denominación de origen del café hondureño. Semana del Café, San Salvador, El Salvador, 15 October.

Ponte, S. (2002) “The 'Latte Revolution'? Regulation, Markets and Consumption in the Global Coffee Chain". World Development, 30 (7): 1099-1122. doi: 10.1016/S0305-750X(02)00032-3.

Quiñones-Ruiz, X.F.; Penker, M.; Vogl, C.R. and Samper-Gartner, L.F. (2015) "Can origin labels re-shape relationships along international supply chains? - The case of Café de Colombia", International Journal of the Commons, 9(1), March: 416-439. doi: 10.18352/ijc.529.

Raynolds, L.T. (2009) "Mainstreaming Fair Trade Coffee: From Partnership to Traceability". World Development, 37 (6): 10831093. doi: 10.1016/j.worlddev.2008.10.001.

Raynolds, L.T.; Murray, D. and Heller, A. (2007) "Regulating sustainability in the coffee sector: A comparative analysis of third-party environmental and social certification initiatives". Agriculture and Human Values, 24: 147-163. doi: 10.1007/ s10460-006-9047-8.

Rueda, X. and Lambin, E. F. (2013) "Linking globalization to local land uses: How eco-consumers and gourmands are changing the Colombian coffee landscapes". World Development, 41: 286-301. doi:10.1016/j.worlddev.2012.05.018.

Sanz Cañada, J. (2016) "Introduction to the 'Special Issue' Local agro-food systems in America and Europe: territorial anchorage and local governance of identity-based foods", Culture and History, 5 (1): e001. doi: http://dx.doi.org/10.3989/chdj.2016.001. this issue.

Sanz Cañada, J. and Macías Vázquez, A. (2005) “Quality certification, institutions and innovation in local agro-food systems: Protected designations of origin of olive oil in Spain". Journal of Rural Studies, 21 (4): 475-486. doi: 10.1016/j.jrurstud.2005.10.001.

Schroeder, K. (2009) "The Case of Blue Mountain Coffee Jamaica". In Guide to Geographical Indications. Linking products and their origins, edited by Giovannucci, D.; Josling, T.; Kerr, W.; O’Connor, B. and Yeung, M.T. International Trade Centre, Geneva: 170-176.

Schüßler, L. (2009) 'Protecting 'Single-Origin Coffee' within the Global Coffee Market: The Role of Geographical Indications and Trademarks". International Law and Trade Policy, 10 (1): 145-189.

Sylvander, B. (2004) Dolphins: Final Report. Synthesis and Recommendations. Le Mans: Dolphins European Union concerted action QLK-2000-00593 by the fifth framework of the European Community for the research, technological development and demonstration activities (1998-2002). http://www.origin-food. org/pdf/wp7/dol_d8.pdf.

Teuber, R. (2010a) "Café de Marcala - Honduras' GI Approach to Achieving Reputation in the Coffee Market". The Estey Centre Journal of International Law and Trade Policy, 10 (1): 131-148.

Teuber, R. (2010b) "Geographical indications of origin as a tool of product differentiation: The case of coffee". Journal of International Food \& Agribusiness Marketing, 22 (3-4): 277-298. doi: 10.1080/08974431003641612.

Thévenod-Mottet, E. and Marie-Vivien, D. (2011) "Legal debates surrounding geographical indications". In Labels of Origin for Food. Local Development, Global Recognition, edited by Barham, E. and Sylvander, B. CABI International. Cambridge, USA: 13-28.

Torres Salcido, G. and Muchnik, J. (2012) "Globalisation/fragmentation process: governance and public policies for localized agri-food systems". In Local agri-food systems in a global world. Market, social and environmental challenges, edited by Arfini, F.; Mancini, M.C. and Donati, M. Cambridge Scholars Publishing, Newcastle upon Tyne, UK: 97-116.

Vandecandelaere, E.; Arfini, F.; Belletti, G. and Marescotti, A. (2009) Linking people, places and products. A guide for promoting quality linked to geographical origin and sustainable geographical indications. FAO, Rome, Italy. 